\title{
Applying Importance-Performance Analysis as a Service Quality Measure in Food Service Industry
}

\author{
Gwo-Hshiung Tzeng', Hung-Fan Chang²
}

\begin{abstract}
As the global economy becomes a service oriented economy, food service accounts for over $20 \%$ of service revenue, with an annual growth rate of more than $3 \%$. Compared to physical products, service features are invisible, and the production and sale occurs simultaneously. There is not easy to measure the performance of service. Therefore, the service quality of catering services is considered to be an important topic of service management. According Market Intelligence \& Consulting Institute (MIC) to apply blog text analyzing to point out top 10 restaurants of blog in Taiwan, what it's popular restaurant in food service industries. This paper attempts to identify both the importance and performance of restaurant service quality in the Taiwan food service industry using the SERVQUAL and IPA model. We can conclude with certainty that three methods (SERVQUAL, IF and IPA) are able to explain significant amount of service quality. At the same time, the service quality factors of IPA model had more comprehensive consideration in comparison to those of SERVQUAL and IF.
\end{abstract}

Keywords: SERVQUAL; Service quality; importance-performance analysis; improvement factor.

\footnotetext{
' National Visiting Professor, Institute of Management of Technology, National Chiao Tung University. I00I University Road, Hsinchu City 300, Taiwan. TEL: +886-2-23I465I5 ext 505, E-mail: ghtzeng@cc.nctu.edu.tw

${ }^{2}$ Ph.D. student, Institute of Management of Technology, National Chiao Tung University. I00I University Road, Hsinchu City 300, Taiwan. TEL: +886-3-57I2 I2I, E-mail: hfchang.mt98g@nctu.edu.tw
} 


\section{Introduction}

Since the 1980s, many studies have explored service quality as a precondition for business excellence and strategies (Ruiqi and Adrian, 2009; Arambewela and Hall, 2006). Previous studies have also showed that service quality affects the quality of business performance (Chen and Tsai, 2006). Plymire (199I) also pointed out that $91 \%$ of customers encountered discomfort or were not satisfied with the service in the course of consumer services; by no means will these customers buy again, and they will go on to complain about the unpleasant experience to 8 to 10 individuals. Huang (2008) also pointed out that to improve consumer loyalty, the business degree of companies has become an important issue. As for the impact of service quality on customer satisfaction, Huang also suggested that loyalty to the regime has a positive impact. Enterprises must maintain good service quality to create customer loyalty to effectively retain customers.

Service quality performance is built up by customer expectation before consumption and consumer experience after consumption (Johnson and Mathews, 1997). Parasuraman et al. (1985) aimed to investigate the service quality expectations of customers and perceived that the differences between the scope of customers' expectations and actual experiences are in the ability of service providers to meet customer expectations. Zeithaml et al. (1988) argued that service quality is a cognitive quality of a product or service. The concept of service quality is derived from the concept of physical product quality (Zeithaml et al., 1988; Parasuraman et al., 1994). Compared to physical products, service features are invisible, and the production and sale occurs simultaneously (Sasser et al., 1978). As service occurs, customers also play a role in co-production (Fitzsimmons and Fitzsimmons, 2006), so it is not easy to measure the performance of service (Lovelock, 1983; Parasuraman et al., 1985).

Parasuraman et al. (1985) proposed the concept of the service quality model, and established consumer perceptions of service quality systems. These perceptions are based on the gap between expectations for customer service and perceived service. Ten service quality dimensions were determined. These factors constitute the gap between customers' expected service and perceived service. Furthermore, service quality dimensions measure the relationship between service quality models. Parasuraman et al. (1988) simplified the measurement of service quality in 1985. The ten dimensions were reduced to five. They also developed SERVQUAL model, composed of the 22 service quality items, including its dimensions: tangible, reliability, responsiveness, assurance and empathy. SERVQUAL, introduced by Parasuraman et al. in 1988 as a way of handling service quality measure, now has many fields of application in service science issues.

As the global economy becomes a service oriented economy, food service accounts for over $20 \%$ of service revenue, with an annual growth rate of more than $3 \%$. Therefore, the service quality of catering services is considered to be an important topic of service management. However, the food service industry has certain characteristic, such as low-tech needs, low capital requirement and low entry barriers. Such characteristics do lead to difficulties in developing sustainable comparative advantages. The service industry is a high-contact service (Brady and Robertson, 1999). Albrecht (199I) argued that the service industry business model continues providing service to solve customer needs. A main characteristic is the different types of manufacturing that support intangible services for the interaction process between individuals and the service industry (Berdie, 1994). Gronroos (1990) believed that service offers active economic value by solving customers' problems. Vargo and Luch (2004) argued that service is a kind of core competitiveness and the value created is shown on the service processes or service procedures for customer needs. Therefore, providing service to meet customer needs is an essential job for managers in the food industry when attempting to satisfy customers so that they are willing to come again.

After Parasuraman et al. (1985) proposed to measure the quality of a service mode, service quality measurement of subjects has become a growing trend attracting wide academic and practical attention. Service quality performance is built up by customer expectation before consumption and consumer experience after consumption (Johnson and Mathews, 1997). The most commonly used measure of service quality is the SERVQUAL scale developed by Parasuraman et al. (1985). In addition to the SERVQUAL service quality model, Martilla and James (1977) proposed Importance-performance analysis (IPA). This analysis tool is commonly used to measure service performance. Deng (2008) pointed out that the IPA method is a performance evaluation tool 
which measures the level of service factors between importance and satisfaction in the service innovation process. Sampson and Showalter (1999) pointed out that the IPA method measures customer importance and satisfaction performance, and develops specific product relations based on attributes of technological priorities. Gemmel (2007) argued that the IPA method achieves excellent service quality to create high customer satisfaction in managers' service quality improvement project. The above-mentioned IPA method offers a pragmatic theoretical basis for important evaluation.

In recent years, blog marketing was a new marketing method in food service industries. According Market Intelligence \& Consulting Institute (MIC) to apply blog text analyzing to point out top 10 restaurants of blog in Taiwan, what it's popular restaurant in food service industries. This paper attempts to identify both the importance and performance of restaurant service quality in the Taiwan food service industry using the SERVQUAL and IPA model. More specifically, the paper intends to discuss blog browser, in terms of importance and performance of popular restaurant service quality. By identifying the needs, desires and expectations of different segments, managers will be in a better position to develop excellent marketing strategies to cater for their customers and to achieve competitive advantages.

For these objectives to be achieved, the article is structured as follows. The section I deals with some background information on the ongoing research within which the present study was carried out and a statement of the specific research question. The section 2 describes the logic of SERVQUAL and IPA model for the collection of data on questionnaire survey. The section 3 , results and discuss for the various analyze are presented following each of these descriptive sections. Finally, conclusions are present and limitation is made for service industry.

\section{Method}

\section{I Questionnaire survey and data collection}

The purpose of this study was to explore service quality for restaurant service quality. This will provide the direction to improve the catering industry and thus to improve service quality. This uses IPA and the SERVQUAL scale proposed by Parasuraman et al. (1988) with five SERVQUAL dimensions as a questionnaire survey. The questionnaire was revised according to the five dimensions of SERVQUAL (Parasuraman et al., 1988). The dimensions are as follows: tangibles, responsiveness, reliability, assurance and empathy. 25 items are included on the third level. To ensure questionnaire reliability and validity, we invited three experts with at least two years of experience of working in consultation services to examine and modify the questionnaire. Therefore, the content validity of the method is confirmed.

A survey was conducted to identify the factors that support or impede influence popular restaurants service quality in Taiwan. The research design was a service quality measured utilizing questionnaire survey method. Likert's five point scale is used as the rating system, the five scales are: agree strongly, agree, neutral, disagree, disagree strongly, which are noted as 5 points, 4 points, 3 points, 2 points and I point. Higher points indicate higher capability or involvement in the specified dimension, whereas lower points indicate lower capability or involvement in the specified dimension. The subjects were tested on restaurants service quality by being asked to measure the factors of blog top 10 restaurants in Taiwan. To ensure some homogeneity of social background, all subjects were selected from the responsible person at customs of blog top 10 restaurants. Using a random sampling approach, every diner passing through the restaurant after the meals was approached and given a questionnaire for self-completion over a survey period per day. The sample was composed of 500 customers for blog top 10 restaurants. Finally, we get 154 questionnaires as feedback; the yield rate is $30.8 \%$.

\subsection{Logic of SERVQUAL and IPA model}

Topics of service quality, including the customer satisfaction and the customer loyalty criteria, both need to be carefully explored in regard to the service quality of restaurants. We applied SERVQUAL to build questionnaire, what it was measuring service quality in popular top 10 restaurants of blog. At the same time, we had a survey was conducted to identify the factors that IPA model. Martilla and James (1977) argued that IPA model was relating of importance and performance on customer perspective. Therefore, we were applied IPA model to measure service quality. Bacon (2003) argued of although various researchers have proposed minor modifications to the technique over the years, the basic framework has largely remained the same. The IPA is graphically presented on a grid divided into four quadrants, that it's illustrated the IPA grid as shown in figure I. 


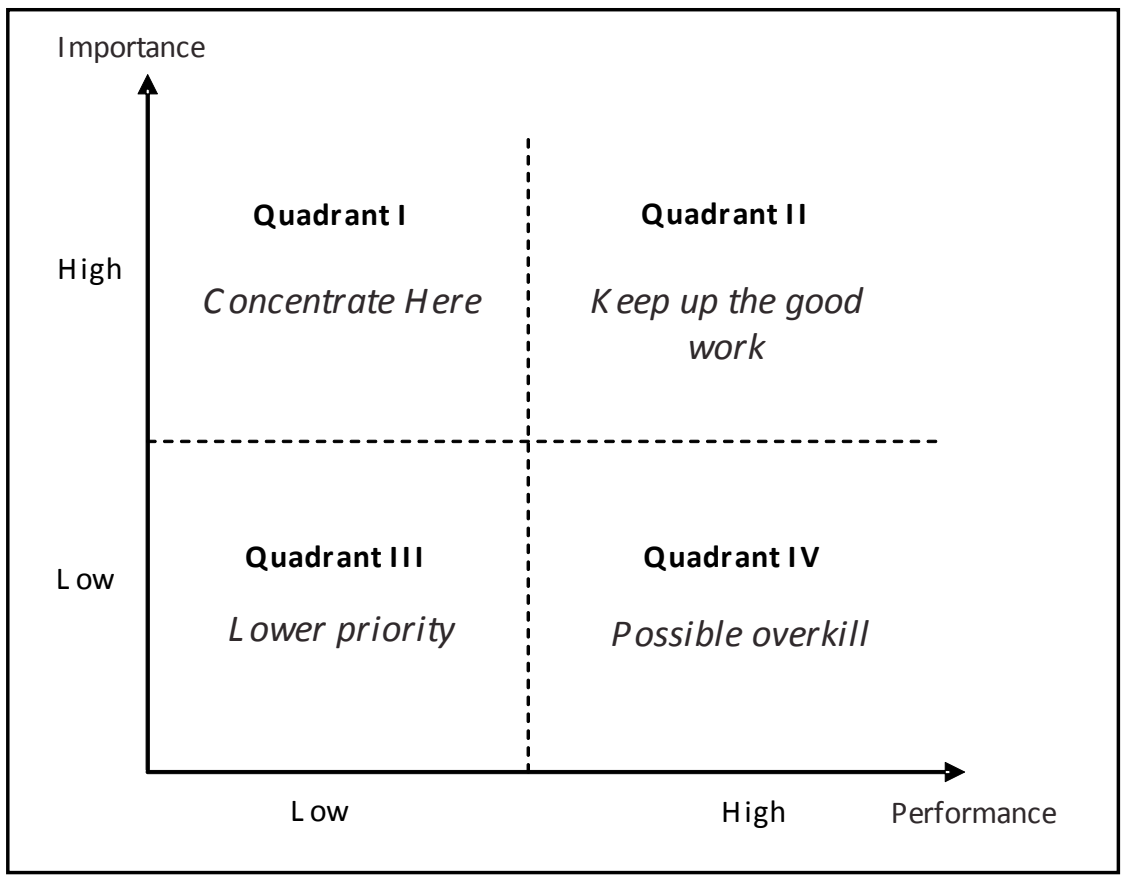

Figure I IPA model

IPA model measures customer importance and satisfaction performance, and develops specific product relations based on attributes of technological priorities (Sampson and Showalter, 1999). The quadrants were according the average of important and satisfaction (performance) to differentiate in IPA model. The four-quadrants and implication of IPA is shown in table I.

\begin{tabular}{|c|c|}
\hline Quadrants & Implication \\
\hline $\begin{array}{l}\text { Quadrant I } \\
\text { Concentrate Here }\end{array}$ & $\begin{array}{l}\text { Attributes are perceived to be very important to respondents, but } \\
\text { performance levels are fairly low. This suggests that improvement efforts } \\
\text { should beconcentrated here. }\end{array}$ \\
\hline $\begin{array}{l}\text { Quadrant II } \\
\text { Keep up the good work }\end{array}$ & $\begin{array}{l}\text { Attributes are perceived to be very important to respondents, and at the } \\
\text { same time, the organization seems to have high levels of performance in } \\
\text { these activities. The message here is to keep up the good work. }\end{array}$ \\
\hline Quadrant III & Attributes here are rated as having low importance and low performance. \\
\hline Lower priority & $\begin{array}{l}\text { A lthough performance levels may be low in this cell, managers should } \\
\text { not be overly concerned, since the attributes in this cell are not perceived } \\
\text { to be very important. Limited resources should be expended on this low } \\
\text { priority cell. }\end{array}$ \\
\hline $\begin{array}{l}\text { Quadrant IV } \\
\text { Possible over kill }\end{array}$ & $\begin{array}{l}\text { This cell contains attributes of low importance, but where performance is } \\
\text { relatively high. Respondents are satisfied with the performance of the } \\
\text { organization, but managers should consider present efforts on the } \\
\text { attributes of this cell as being superfluous/unnecessary. }\end{array}$ \\
\hline
\end{tabular}

Table I Quadrant and implication of IPA 
Improving of service quality should be following the ranking of satisfaction and customer needs, that it's not only focus on importance. Therefore, Yang (2002) made up this question, that definition of the "improvement factor (IF)", as shown in equation I.

I mprovement factor $(I)=\frac{\text { Satisfaction }- \text { Importent }}{\text { Importent }}$

The factors of satisfaction will be lower than importance, $\mathrm{I}<0$. Therefore, when $\mathrm{I}<0$, and $|\mathrm{I}|$ will be greater, the factors was more needs to be improved. This method will be grasping customer needs more precision, that it's applying the different between of satisfaction and important. Therefore, we applied IPA model and improvement factor to measure the service quality of popular top 10 restaurants of blog.

\section{Results and discussion}

This study focuses on a proper service quality project for popular top 10 restaurants of blog in Taiwan. The research subjects on the empirical study, we deliver 500 questionnaires and get 154 questionnaires as feedback; the yield rate is $30.8 \%$. Reliability analysis is focused on the internal consistency of the questionnaire and the direction of the study. Cronbach's alpha coefficient helps to assure the conformity for every dimension's critical items. According to Byrne (1994) argued that the Cronbach's alpha coefficient above 0.7 indicates valid reliability. For the reliability analysis of the studied model, Cronbach's alpha coefficient is above 0.7 , and critical items of every dimension are conform to the content, thus, the results are reliable, as shown in table 2. Explore the service quality measure factors for restaurants, as shown in table 3.

\begin{tabular}{|ccccc|}
\hline Dimensions & $\begin{array}{c}\text { Sample } \\
\text { number }\end{array}$ & $\begin{array}{c}\text { Average } \\
\text { satisfaction }\end{array}$ & $\begin{array}{c}\text { Average } \\
\text { importance }\end{array}$ & Cronbach $\boldsymbol{\alpha} \alpha$ \\
\hline Tangible & 154 & 2.66 & 3.21 & 0.85 \\
Reliability & 154 & 1.98 & 3.30 & 0.75 \\
Responsiveness & 154 & 2.19 & 3.33 & 0.79 \\
Assurance & 154 & 2.64 & 2.79 & 0.85 \\
Empathy & 154 & 2.97 & 3.10 & 0.78 \\
Total & 154 & 2.49 & 3.15 & 0.83 \\
\hline
\end{tabular}

Table 2 Internal consistency of the constructs 


\begin{tabular}{|c|c|c|c|c|c|c|c|c|c|c|}
\hline & Dimensions & Questions & Satisfaction & Ranking & Importance & Ranking & SERVQUAL & Ranking & IF & Ranking \\
\hline Q1 & & Clean and comfortable environment, regular cleaning staff. & 3.73 & 1 & 3.6 & 2 & 0.13 & 11 & 0.04 & 11 \\
\hline Q3 & & Restaurant supply customers with adequate seating and space. & 1.52 & 13 & 2.78 & 13 & -1.26 & 5 & -0.45 & 5 \\
\hline Q4 & & An adequate supply of food and fresh, health. & 1.72 & 10 & 3.43 & 4 & -1.71 & 2 & -0.50 & 4 \\
\hline Q5 & Reliability & Equi pped kitchen, cooking-oriented health personnel. & 1.5 & 14 & 3.14 & 8 & -1.64 & 3 & -0.52 & 2 \\
\hline Q6 & & Restaurants with more than one certification audit qual ity. & 2.73 & 6 & 3.34 & 5 & -0.61 & 8 & -0.18 & 8 \\
\hline Q7 & & Service providers quickly and accurately. & 1.71 & 11 & 3.89 & 1 & -2.18 & 1 & -0.56 & 1 \\
\hline Q8 & Responsiveness & Immediate response to customer demands. & 1.46 & 15 & 2.98 & 10 & -1.52 & 4 & -0.51 & 3 \\
\hline Q9 & & $\begin{array}{l}\text { Customer needs in accordance with appropriate adjustments in the } \\
\text { process. }\end{array}$ & 3.39 & 4 & 3.11 & 9 & 0.28 & 12 & 0.09 & 12 \\
\hline Q10 & & $\begin{array}{l}\text { The behaviour of personnel in excellent restaurants will instill } \\
\text { confidence in customers. }\end{array}$ & 3.71 & 2 & 3.31 & 6 & 0.4 & 14 & 0.12 & 13 \\
\hline Q11 & Assurance & $\begin{array}{l}\text { Personnel in excellent restaurants will be consistently courteous with } \\
\text { customers. }\end{array}$ & 1.54 & 12 & 2.74 & 14 & -1.2 & 6 & -0.44 & 6 \\
\hline Q12 & & $\begin{array}{l}\text { Personnel in excellent restaurants will have the knowledge to answer } \\
\text { customers' questions. }\end{array}$ & 2.66 & 7 & 2.33 & 15 & 0.33 & 13 & 0.14 & 14 \\
\hline Q13 & & Excellent restaurants will give customers individual attention. & 3.68 & 3 & 2.97 & 11 & 0.71 & 15 & 0.24 & 15 \\
\hline Q14 & Empathy & $\begin{array}{l}\text { Excellent restaurants will have staff, who to give customers personal } \\
\text { attention. }\end{array}$ & 2.59 & 9 & 3.44 & 3 & -0.85 & 7 & -0.25 & 7 \\
\hline Q15 & & $\begin{array}{l}\text { The personne of excellent restaurants will understand the specific } \\
\text { needs of their customers. }\end{array}$ & 2.64 & 8 & 2.89 & 12 & -0.25 & 10 & -0.09 & 10 \\
\hline
\end{tabular}

Table 3 Results of SERVQUAL and IF 
The ranking of SERVQUAL for satisfaction is subtracting to importance. According to the investigation of SERVQUAL of the service quality of the restaurants in this research, "service providers quickly and accurately" ranked first in terms of improvement factor, and the weight was -2.18 . This result was the same with IF. "An adequate supply of food and fresh, health" and "equipped kitchen, cookingoriented health personnel" was then evaluated as the second and third improvement factor in terms of deciding whether to appreciate the service quality of restaurant, respectively. It is worth notice that the third of IF was "immediate response to customer demands"; this is not consideration in SERVQUAL. As was mentioned above, although SERVQUAL can help us to make rank of service quality improvement factor. But there are not consider the different of satisfaction and importance. Thus, in addition to improvement factors of SERVQUAL, the other improvement factors of IF also need to be taken into consideration in the service quality improvement ranking.

In addition, we used the mean of all implicitly derived degrees of importance for attributes and the mean of all performance for attributes to divide the IPA matrix into four quadrants, as shown in figure 2 .

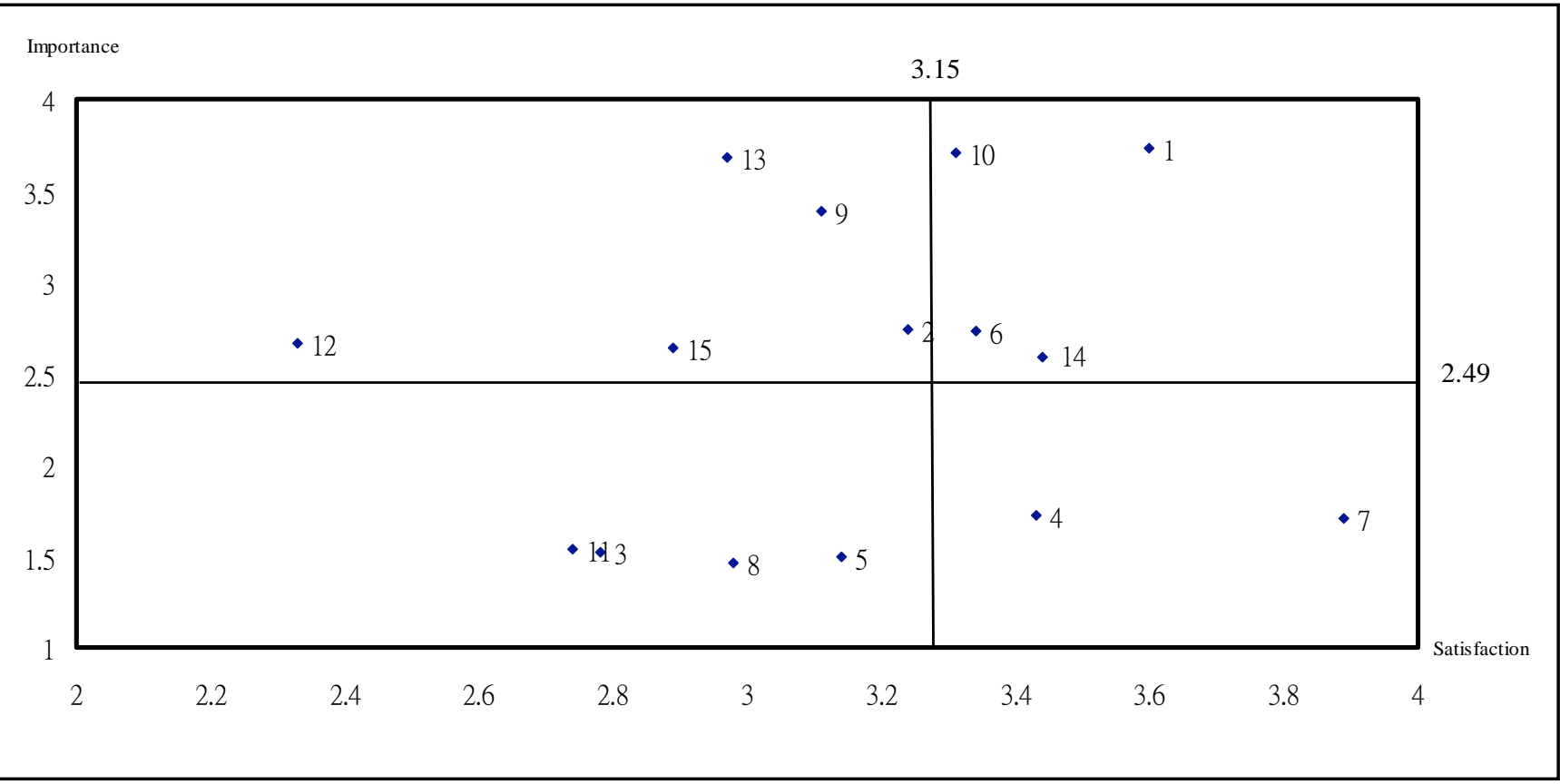

Figure 2 Result of IPA model

As shown in figure 2, "concentrate here" of quadrant-I was key success factors to improve service quality, but performance levels are fairly low. This suggests that improvement efforts should be concentrated here, included Q2, Q9, QI2, QI3 and QI5. The service quality factors of IPA model had more comprehensive consideration in comparison to those of SERVQUAL and IF. "Keep up the good work" of quadrant-II was perceived to be very important to customers. At the same time, the restaurant looks to have high levels of performance, included QI, Q6, QI0 and QI4. "Lower priority" of quadrant-III was having low importance and low satisfaction (performance). There were underappreciated in IPA model. Therefore, managers should not be overly concerned, included Q3, Q5, Q8 and Q1I. "Possible overkill" of quadrant-IV had low importance, but where performance is relatively high. Their service quality was exceeding customer needs. Thus, managers of restaurant should consider present efforts as being unnecessary, included Q4 and Q7.

"Keep up the good work" ranked first in terms of service quality improvement factor, that it was perceived to be very important to customers. As was mentioned 
above, the service quality factors of IPA model had more comprehensive consideration in comparison to those of SERVQUAL and IF. Thus, the priority improvement factors were included QI, Q6, QI0 and QI4. Their advocated principles such as the following:

(I) As for tangible, "clean and comfortable environment, regular cleaning staff" is currently the most important factor because dining quality and cleanliness are the core components of customer service (Grönroos, 1990). Tangibility of the entity is characterized by customer volume in the value of intangible services and alternative indicators. For example, restaurants supply customers with adequate seating and space, clean and comfortable environment, regular cleaning staff and environment. Managers should be able to provide customer-oriented services to ensure that tangible quality of service.

(2) As for reliability, "restaurants with more than one certification audit quality" is currently the most important factor because service staff attitudes and professional skills affect the customer satisfaction (Menon et al., 2000). To improve service staff attitudes and technology, managers should further emphasize the technical expertise of the service staff of to resolve customer questions and establish the professional image.

(3) As for assurance, "the behaviour of personnel in excellent restaurants will instill confidence in customers" is currently the most important factor because customers have the highest requirements for the restaurant kitchen sanitation (Baker, 1996). When customers are in the process of eating meals, dirty environment and tableware are shortcomings which cannot be tolerated. Indeed, the management must pay attention to keeping the kitchen and utensils clean.

(4) As for empathy, "excellent restaurants will have staff, who to give customers personal attention" is currently the most important factor because marketing strategies are tailored to truly meet the needs of customers. Excellent restaurants have staff who give customers personal attention, and proactively provide customers with quality services to help enterprises accumulate sustainable competitive advantage and value creation.

\section{Conclusion and limitation}

Service innovation of quality performance perspective, introduced by IBM innovation service project in 2003 as a way of improving innovation capability and quality performance in service industries, now has many field of application in service industry management. We applied SERVQUAL to measure service quality for popular top 10 restaurants of blog, and at the same time, added IPA model to enhance evaluation improvement factor of service quality. Such as this methods can help to improve service quality. There is improving custom satisfaction and loyalty to import improvement factors of "keep up the good work", that it's creating service differentiation and innovation advantages.

We can conclude with certainty that three methods (SERVQUAL, IF and IPA) are able to explain significant amount of service quality. Two of these findings are worth summarizing. First, the service quality factors of IPA model had more comprehensive consideration in comparison to those of SERVQUAL and IF. Second, measuring service quality factors as proposed by Parasuraman et al. (1988), among the five dimensions in this study, "responsiveness" is the most important. The main meaning of this is that enterprises should respond immediately to customer needs in accordance with appropriate adjustments in the process. Service-oriented enterprises create the customer needs rather than "meeting customer needs" to shape the life and situation, creating mental and physical experiences to attract the attention of customers to change their consumption behavior. At the same time, the high relative importance of "responsiveness", the other four dimensions also need to be taken into consideration in the service quality model structure.

These conclusion needs to be treated with caution, however. There are a number of possible explanations for this conclusion. SERVQUAL and IPA were constructed to measure the calculation of appropriate weightings for service quality improvement factors in popular top 10 restaurants of blog. One explanation for this is that it is very user-friendly and can also be used for solving general service quality measure issues in real practice and in research.

Another problem that often arises in data gathering has to do with the face that such studies are often based on a survey, that is, the data are gathered through questionnaire survey, interviews, and so forth. The convenience sample 
of respondents must be acknowledged. Although quality is found to be measured most accurately through the eyes of the customer. Some might argue that customers are not the only group to survey in assessing service quality in food industries, since they are in the management process their subjective. These stakeholders include managers and employers. Additional research is needed to develop appropriate instruments targeted to these audiences as part of a service quality improved factors assessment program.

\section{References}

ALBRECHT, K. (|99|). Total quality service. Executive Excellence, 8, 18-19.

ARAMBEWELA, R. and Hall, J. A. (2006). Comparative Analysis of International Education Satisfaction Using SERVQUAL. Journal of Services Research, 6, 14I-163.

BACON, D. (2003). A comparison of approaches to importance-performance analysis. International Journal of Market Research, 45, 55-7I.

BAKER, J. and Cameron, M. (1996). The Effects of the Service Environment on Affect and Consumer Perceptions of Waiting Time: An Integrative Review and Research Proposition. Journal of the Academy of Marketing Science, 24(4), 338-349.

BERDIE,D.R.(1994). ReassessingtheValue ofHigh Response Rates to Mail Surveys. Marketing Research, I, 52-64.

BRADY, M. K. and Robertson, C. J. (1999). An exploratory study of service value in the USA and Ecuador. International Journal of Service Industry Management, 10, 469-486.

BYRNE, B. M. (1994). Structural equation modeling with EQS and EQS/Windows. Sage, Newbury Park.

CHEN, C. F. and Tsai, D. C. (2006). How Destination Image and Evaluative Factors Affect Behavioral Intentions? Journal of Tourism Management, 28, III5-II22.

CHU, R. K. S. and Choi, T. (2000). An importanceperformance analysis of hotel selection factors in the Hong Kong hotel industry: A comparison of business and leisure travelers. Tourism Management, 2I(4), 363-377.
DENG,W.J.(2008). Fuzzyimportance-performanceanalysis for determining critical service attributes. International Journal of Service Industry Management, 19, 252-270.

FITZSIMMONS, J. A. and Fitzsimmons, M. J. (2006). Service Management. McGraw Hill, New York.

GEMMEL, P. (2007). Delivering Excellent Service Quality in Aviation: A Practical Guide for Internal and External Service Providers. International Journal of Service Industry Management, 18, 443-444.

GRONROOS, C. (1983). Strategic Management and Marketing in the Service Sector. Marketing Science Institute, Boston.

GRÖNROOS, C. (1990). Services Management and Marketing: Managing the Moments of Truth in Service Competition. Lexington Books, MA.

HUANG, W. H. (2008). The impact of other-customer failure on service satisfaction. International Journal of Service Industry Management, 19, 521-536.

JOHNSON, C. and Mathews, B. P. (1997). The influence of experience on service expectations. International Journal of Service Industry Management, 8, 290-305.

LOVELOCK, C.H. (1983). Retailing Strategies for Public and Nonprofit Organizations. Journal of Retailing, 59, 93-II5.

MARTILLA, J. A. and James, J. C. (1977). Importanceperformance analysis. Journal of Marketing, 4I, 77-79.

MENON, K. and Dube, L. (2000). Ensuring Greater Satisfaction by Engineering Salesperson Response to Customer Emotions. Journal of Retailing, 76(3), 285-307.

PARASURAMAN, A., Zeithaml, V. A. and Berry, L.L. (1985). A conceptual model of service quality and its implications for future research. Journal of Marketing, 49, 4I-50.

PARASURAMAN, A., Zeithaml, V. A., Berry, L. L. (1988). SERVQUAL: a multiple-item scale for measuring consumer perception of service quality. Journal of Retailing, 64, 12-40. 
J. Technol. Manag. Innov. 20II,Volume 6, Issue 3 